have been included is Lionel Dorge's Introduction à l'étude des FrancoManitobains: Essai historique et bibliographique (Saint-Boniface, 1973, 298p.)

It is inevitable that in such a labour of love there should be some mistakes, but the proof-readers of this volume overlooked rather too many. Claude Thibault's Bibliographia Canadiana (p. xi) contains 795 pages (not 195), item 113 should read Fonseca (not Tonesca), item 128 Gaboury (not Laboury), item 185 Deposition (not Disposition), item 308 Bercuson (not Barcuson), item 802 should presumably be "abonnés" (not abbones), item 1064 should be Marlyn (not Marley), item 1136 should be Baudoux (not Baudous), and I have a list of 'other such lapses too numerous to mention. There are some inconsistencies as well. The Ukrainian titles of items $815,816,824$ and 825 are translated into English in parentheses, but not the titles of 817 and 834; nor the Icelandic title of item 808 . The most regrettable (and quite unnecessary) defects occur as a result of printing the book from a typewriter lacking French accents. In the early pages the accents have been added manually, but this was soon abandoned and the French titles in the latter part of the book carry no accents whatever.

These lapses notwithstanding, this centennial bibliography of Winnipeg will be welcomed by students and laymen alike. Copies may be obtained from Ms. Louise Sloane, University of Winnipeg Library, Winnipeg. R3B 2E9. (Cheques should be made payable to the Manitoba Library Association.)

\title{
Lovell Clark
}

(Dr. Clark teaches history at the University of Manitoba, Winnipeg, and is a specialist in Western history. He is the author of several important articles and books, including his monographs The Manitoba School Question: Majority Rule or Minority Rights? 1968, and The Guibord Affair, 1971.)

Canadian Books in Print 1973, edited by Harald Bohne. Toronto: University of Toronto Press, [1974]. 826 p. $\$ 20.00$

The latest edition of Canadian Books in Print covers the first eight months of 1973, including entries submitted by Canadian publishers up to 31 August of that year, a total of 14,295 titles (multiple volume listings counted as one), 1,890 of them published under a 1973 imprint. "Forthcoming" titles are also listed, a questionable practice as some of these will prove in the end to be ghosts; and those that do, in fact, appear will likely be more expensive than the advance list price.

Unlike Canadiana (National Library of Canada), Canadian Books in Print does not include books by Canadian authors published abroad or foreign books 
about Canada and Canadians. Moreover, it does not attempt to include more than a token listing of provincial and federal government publications, confining the selection to those of general interest usually obtainable in bookstores - a difficult criterion to apply. The only French-language titles listed are those published by predominantly English-language publishers, as it seemed quixotic to duplicate the titles that annually appear in Répertoire de l'édition au Québec.

Every compilation of this kind has its shortcomings; the superior quality of this volume is due in large measure to the careful editing of Harald Bohne of the University of Toronto Press. A very useful reference work, it will be indispensable for order librarians and booksellers. Reprint publishers and instructors in Canadian studies will be able to find out from its pages which Canadian 'classics' are still in print (or reprint).

It is not, nor is it intended to be, a book of special interest to scholars. Thumbing through its pages, however, one can form some impression of the present Canadian literary scene, and can discover which older Canadian books have retained sufficient popularity to warrant reprinting. The once famous 'group of the sixties' (Canadian poets born in the 1860s) is now in limbo - in this listing there is not to be found a single volume of verse by Charles G.D. Roberts, Bliss Carman, Archibald Lampman, William Wilfred Campbell, Duncan Campbell Scott or Rev. Frederick George Scott. Pauline Johnson survives with one title to her credit, a reprint of Flint and Feather (1957). Sir Gilbert Parker, that prolific writer of romantic fiction and verse (some thirty volumes listed by Watters) is represented only by The Seats of the Mighty; Ralph Connor, run-away best seller of his day, only by two of his Glengarry novels. Mazo de la Roche, on the other hand, must still be Canada's most popular novelist with no fewer than thirty-five titles still in print. Among the historians, G.M. Wrong is reduced to one reprint (Louisbourg in 1745); Donald Creighton has eight historical works in print to Arthur Lower's four; and so it goes.

The table of contents of Canadian Books in Print indicates a three-fold index, first by authors, then by titles, and finally by publishers. In point of fact, however, it does not supply a list of books in print by any given Canadian publisher. The publisher index is merely a translating of the short forms used in the other indices into the full names and addresses of the seven hundred and eight 'publishers' included in the volume. The overwhelming majority of these are, of course, not publishing houses at all; they are institutes, societies, associations, university departments, and public bodies of one sort or another that occasionally issue reports, studies, monographs or other publications. Fully operational university presses in Canada may be counted on one's fingers, but fifty-eight 'publishers' herein listed have a direct university connection. Privately printed books - and there is a surprising number of them - are usually listed under the authors' names as publishers. Then there are the various ethnic presses, many of them, for some strange reason, under the letter "P" - Pagurian, Pekonen, Pendejo, Percépic and Presunka! And who, or what, are "Felindical Publications" or "Granny Soot Publications"?

Seven hundred and eight Canadian 'publishers' - or, say, seven hundred, to take care of purely foreign encroachments - and the list does not pretend to be definitive! With so great a cloud of witnesses to the importance placed on the printed word in Canada, is it not strange that the state of Canadian 
publishing is so parlous that the Ontario Royal Commission on Publishing prefaces its multiple recommendations with the remark that "Public concern should lie first with conserving a Canadian book publishing capacity." Sad indeed it would be to see these publishers gradually taken over one by one by foreign agencies. Perhaps the last to succumb would be the Ontario publisher listed on page 808 as "Corp. of the Village of Cannington."

\section{H.P. Gundy}

(After retiring as University Librarian from Queen's, Mr. Gundy became Professor of English Language and Literature, Editor of Queen's Quarterly, Associate Director and General Editor of McGill-Queen's University Press. Now retired and living in Toronto, he is Chairman of the Publications Committee, Bibliographical Society of Canada, and Editor of Historic Kingston.)

A Canadian Indian bibliography, $1960-70$, by T.S. Abler, D.E. Sanders, S.M. Weaver. Toronto University of Toronto Press, 1974. xii, 732 p. maps. $\$ 35.00$

This book is a welcome addition to the bibliography of the Canadian Indian, there being few on the subject, and none so exhaustive for the period it covers. It will be of most use to anthropologists, sociologists, lawyers, and other white people working with or studying Indians and Metis. The Eskimos are not included, as they are well covered in The Arctic Bibliography.

For this book, a total of 3038 items were drawn from books, periodicals, theses, unpublished papers, reports and government documents. These have been furnished with three to eighteen-line abstracts, and arranged in three sections: first the subjects, such as history, demography, economics; next a section of case-law digests going back to 1st July, 1867; and finally items subdivided by the tribes of Canada. This is a subject bibliography compiled by subject specialists. The bias is toward sociology and anthropology, with special completeness in government documents, though there are many items on art, religion and literature as they fall within the cultural aspect of the compilers' criteria.

I must say the indexing is poor. There are two subject indexes, one for the case-law digest and one for the other items, and that's the only approach other than the classed arrangement of the chapters. Within the individual subject references there are no subdivisions. An item such as Folklore contains 96 references to both particular and general works. There is no author/title listing. Too bad. This limits the usefulness of the work. However, the subject of Native peoples is so important that we should be happy to have this scholarly, comprehensive work, and wade through it as best we can.

\section{Stuart MacKinnon}

(Mr. MacKinnon is the Bibliographer in Special Collections, Douglas Library, Queen's University at Kingston, and he has a special interest in the Native peoples of Canada. Mr. Mackinnon is also a noted poet, and his recent publications include The Intervals, Coach House Press, 1974.) 